\title{
KETERLIBATAN MASYARAKAT DALAM PENGEMBANGAN PARIWISATA DI DESA WISATA TABALANSU, PAPUA
}

\author{
Ika Pujiningrum Palimbunga \\ Prodi Magister Kajian Pariwisata Universitas Udayana \\ Email: ika.palimbunga@gmail.com
}

\begin{abstract}
Tourism has begun to develop in the village of Tablanusu. The community as a major component in tourism development plays an important role to develop the local potentialities of nature and culture. The purpose of this study is to identify the forms of community participation in tourism development in Tablanusu village. This study uses descriptive qualitative method, the technique of collecting data through observations, interviews and documents study. This study was conducted at the Tablanusu village. Informants in this study were 17 people selected by purposive sampling. This research uses the theory of participation. The results of the study reveal the form of participation in planning, implementation, and monitoring. The research results suggest the government to support the community to improve the quality of human resources, building infrastructures which are still lacking, and make good cooperation between tourism stakeholders including the local community in Tablanusu village.
\end{abstract}

Keywords: Participation, Community, Tourism Development, Tablanusu Village.

\section{Pendahuluan}

Dapua adalah salah satu provinsi yang terletak di bagian timur 1 Indonesia yang memiliki kekayaan alam mineral baik itu tembaga, nikel dan emas. Selain kekayaan alam mineral, Papua juga memiliki keindahan pesona alam yang menakjubkan yang perlu dikelola dengan baik. Keindahan alam ini memiliki daya tarik yang dapat dimanfaatkan sebagai daya tarik wisata di Pap- 
ua. Salah satu kabupaten yang sedang mengembangkan pariwisatanya adalah Kabupaten Jayapura. Kabupaten Jayapura terdiri dari 19 distrik, 139 desa dan lima kelurahan dengan suku dan bahasa yang berbeda. Dari keanekaragamanan suku dan bahasa yang ada mencerminkan adanya budaya yang masih melekat di kalangan masyarakat lokal. Pariwisata kini mulai berkembang di salah satu desa yang telah dijadikan destinasi wisata adalah Desa Tablanusu yang diartikan dalam bahasa daerah adalah sebagai matahari terbenam. Keanekaragaman dan keunikan alam dan budaya yang terdapat di Desa Tablanusu sangat potensial untuk dikembangkan sebagai daya tarik wisata (Yarisetouw 2012). Desa Tablanusu terletak di Distrik Depapre, Kabupaten Jayapura Provinsi Papua. Obyek utama desa wisata ini adalah Pantai Tablanusu. Desa ini memiliki luas sekitar 230,5 hektar yang didiami 10 suku, yaitu Suku Sumile, Danya, Suwae, Apaserai, Serantow, Wambena, Somisu, Selli,Yufuwai, dan Yakarimilena.

Sejak Tahun 2008, Pemerintah Daerah Kabupaten Jayapura telah menetapkan desa ini sebagai desa wisata. Desa Tablanusu dijadikan salah satu desa wisata karena desa tersebut memiliki berbagai potensi yang dapat dikembangkan untuk mendukung sektor lainnya. Potensi yang dimiliki Desa Tablanusu antara lain keunikan alam, adat istiadat, flora dan fauna, bahasa serta budaya. Wisatawan dapat menikmati wisata hutan, wisata pantai, wisata telaga air tawar, wisata sejarah, dan wisata budaya. Keunikan Desa Wisata Tablanusu ini adalah seluruh wilayah desa ini diselimuti batu koral hitam. Desa Tablanusu memiliki lokasi yang strategis karena berdekatan dengan dua pantai yang merupakan obyek wisata favorit di Distrik Depapre, yaitu Pantai Amay dan Harlem. Pantai Amay dapat ditempuh dengan menggunakan jalur transportasi perahu. Pantai ini merupakan pusat bagi masyarakat lokal menjual hasil kebun seperti buah rambutan dan matoa. Sedangkan, pantai Harlem, yang juga dikenal dengan sebutan virgin beach, menawarkan pemandangan pantai dengan degradasi warna yang menarik.

Pengembangan pariwisata yang ideal akan memperhatikan 
pelestarian lingkungan, melibatkan peran pemerintah dan masyarakat lokal. Pengembangan pariwisata yang melibatkan masyarakat sangat penting dengan tujuan membuka lapangan kerja bagi masyarakat lokal, memberikan pemahaman tentang pariwisata, serta meningkatkan kondisi perekonomian masyarakatnya. Pariwisata memiliki prospek yang sangat besar jika dikembangkan dengan baik, selain melestarikan potensipotensi yang dimiliki oleh Desa Tablanusu, peningkatan dan pembenahan sarana dan prasarana serta partisipasi masyarakat. Untuk dapat mengembangkan kegiatan pariwisata tersebut diperlukan sebuah pengelolaan yang baik dengan didukung oleh sumber daya manusia yang ahli, berkomitmen serta berpengalaman dalam bidang pariwisata. Terbatasnya sumber daya manusia yang berpengalaman di bidang pariwisata menjadi salah satu hambatan pelaksanaan kegiatan pariwisata di Desa Wisata Tablanusu. Pada dasarnya pengembangan pariwisata di Desa Tablanusu sangat penting untuk dilakukan, meskipun saat ini sebagian besar masyarakat lokal Desa Tablanusu masih sebatas berpartisipasi dalam sektor informal, namun pengembangan pariwisata akan memberikan perubahan bagi masyarakat lokal. Berdasarkan latar belakang masalah tersebut, maka masalah dalam penelitian ini dirumuskan sebagai berikut: bagaimana bentuk partisipasi masyarakat dalam pengembangan pariwisata di Desa Wisata Tablanusu, Papua.

\section{Teori dan Metode}

Teori yang digunakan dalam artikel ini adalah teori partisipasi Arnstein (1969) yang mendefinisikan strategi partisipasi berdasarkan distribusi kekuasaan antara masyarakat dengan badan pemerintah. Dalam teorinya, Arnstein (1969) menjelaskan partisipasi masyarakat yang identik dengan kekuasaan masyarakat, dengan menggunakan metafora tangga partisipasi yang berjumlah delapan anak tangga. Setiap anak tangga mewakili strategi partisipasi yang berbeda yang didasarkan pada distribusi kekuasaan antara pemerintah dengan 
masyarakat yang bersangkutan. Dua anak tangga terbawah merepresentasikan kondisi tanpa partisipasi masyarakat yang meliputi kondisi manipulasi dan terapi. Anak tangga berikutnya, dari tiga hingga lima, mewakili kondisi tokenisme dimana pemerintah melakukan tindakan simbolis atau sekedarnya untuk memunculkan partisipasi masyarakat demi mencapai tujuan yang diinginkan. Ketiga tangga tersebut meliputi kondisi menginformasikan, memberikan konsultasi, dan penentraman. Partisipasi masyarakat yang sesungguhnya terlihat pada tiga tangga terakhir, yaitu kemitraan, pendelegasian wewenang, dan pengendalian masyarakat. Pada tangga teratas, yaitu pengendalian masyarakat inilah terjadi partisipasi masyarakat secara penuh.

Pitana (2002), menyatakan bahwa partisipasi tidak hanya merupakan kontribusi tenaga, waktu, dan materi lokal secara cuma-cuma, untuk mendukung berbagai program dan proyek pembangunan melainkan sebagai suatu keterlibatan secara aktif dalam setiap proses. Peran aktif yang dimaksud adalah mulai dari perencanaan, penentuan rancangan, pelaksanaan sampai dengan pengawasan dan penikmat hasilnya atau yang dikenal dengan "genuine participation" atau dengan kata lain masyarakat sebagai pelaku pariwisata.

Teknik dan metode pengumpulan data dengan observasi, wawancara mendalam, dan dokumentasi. Penentuan informan dilakukan dengan menggunakan metode purposive sampling yang terdiri dari unsur pemerintah Dinas Kebudayaan dan Pariwisata Kabupaten Jayapura dan Dinas Pariwisata dan Ekonomi Kreatif Provinsi Papua, aparat Desa Wisata Tablanusu dan tokoh masyarakat (tokoh Agama, Adat dan Pemuda). Analisis data menggunakan analisis deskriptif kualitatif.

\section{Bentuk Partisipasi Masyarakat di Desa Wisata Tablanusu}

Bentuk partisipasi berupa keterlibatan masyarakat yang dimulai dari proses awal perencanaan, pelaksanaan, dan pengawasan terhadap pengembangan pariwisata di Desa Tablanusu. Partisipasi masyarakat terbagi menjadi dua yaitu 
partisipasi masyarakat terkait dengan program-program didukung oleh Dinas Pariwisata Ekonomi Kreatif Provinsi Papua dan Dinas Kebudayaan dan Pariwisata Kabupaten Jayapura dan partisipasi masyarakat dalam sektor informal.

\section{Partisipasi Masyarakat dalam Perencanaan}

Perencanaan yaitu proses yang menyangkut upaya yang dilakukan untuk mengantisipasi kecenderungan di masa yang akan datang dan penentuan strategi yang tepat untuk mewujudkan target dan tujuan organisasi. Kegiatan dalam perencanaan yaitu keterlibatan masyarakat lokal terutama berkaitan dengan identifikasi masalah atau persoalan, identifikasi potensi pengembangan, analisis, dan peramalan terhadap kondisi lingkungan di masa mendatang, pengembangan alternatif rencana dan fasilitas, dan sebagainya (Sunaryo 2013).

Menurut Ericson (dalam Slamet 1994) menyatakan bahwa bentuk partisipasi di dalam tahap perencanaan (idea planning stage) adalah pelibatan seseorang atau sekelompok orang pada tahap penyusunan rencana dan strategi dalam penyusunan kepanitiaan dan anggaran pada suatu kegiatan. Partisipasi masyarakat Desa Tablanusu pada tahap perencanaan yaitu masyarakat diikutkan dalam musyawarah yang membahas aspirasi masyarakat lokal Desa Tablanusu yang terlibat dalam kegiatan pariwisata di desa ini. Musyawarah ini dihadiri oleh perangkat Desa Tablanusu, Ketua RT dan RW dan tokoh masyarakat. Pada musyawarah ini masyarakat diberi kesempatan untuk menyampaikan pendapat dan aspirasi dengan membentuk kelompok yang beranggotakan empat sampai enam orang. Setiap kelompok yang terbentuk kemudian mengajukan usulan dan pendapat tentang kebutuhan masyarakat terhadap pengembangan desa yang didampingi oleh aparat desa sebagai penasehat.

Masyarakat diikutkan dalam musyawarah perencanaan pengembangan desa, namun keputusan serta langkah selanjutnya dilaksanakan oleh pemerintah. Hal ini menunjukkan bahwa peran masyarakat hanya sebatas memberikan ide, pendapat maupun 
saran pada musyawarah namun tidak ada jaminan bahwa pendapat serta saran masyarakat akan dipakai untuk membuat kebijakan. Dalam tahap perencanaan, pengembangan pariwisata difokuskan pada beberapa program yang dianggap sesuai dengan kebutuhan masyarakat lokal Desa Tablanusu dan programprogram yang bertujuan melibatkan partisipasi masyarakat Desa Tablanusu.

Pada tahap perencanaan, masyarakat diberi kesempatan untuk memberikan pendapat dan saran untuk perencanaan program-program pengembangan pariwisata di Desa Tablanusu namun keputusan tetap dikeluarkan oleh pihak pemerintah. Hal ini menunjukan bahwa partisipasi masyarakat dalam perencanaan berada pada tahapan terapi (therapy). Pada tahapan terapi (therapy) telah ada komunikasi namun bersifat terbatas. Inisiatif datang dari pemerintah dan hanya satu arah. Peran serta masyarakat diberikan kesempatan untuk berpendapat dan didengar pendapatnya, tetapi mereka tidak memiliki kemampuan untuk mendapatkan jaminan bahwa pandangan mereka akan dipertimbangkan oleh pemegang keputusan. Peran serta pada jenjang ini memiliki kemungkinan yang sangat kecil untuk menghasilkan perubahan dalam masyarakat.

\section{Partisipasi Masyarakat dalam Pelaksanaan Program Pemerintah}

Bentuk partisipasi masyarakat Desa Tablanusu dalam pengembangan Desa Tablanusu dapat dilihat dari keterlibatan masyarakat dalam berbagai kegiatan yang telah disepakati oleh masyarakat dan Dinas Pariwisata dan Ekonomi Kreatif Provinsi Papua, Dinas Kebudayaan dan Pariwisata Kabupaten Jayapura dalam pelaksanaan pengembangan pariwisata di Desa Tablanusu.

a. Pelaksanaan bimbingan teknis penguatan ketrampilan bidang kepemanduan wisata lokal bagi kelompok sadar wisata (POKDARWIS) dilaksanakan pada tahun 2011. Program pelatihan terpadu yang dilaksanakan Dinas Pariwisata Ekonomi Kreatif Provinsi Papua dalam rangka meningkatkan kualitas sumber 
daya manusia khususnya masyarakat lokal yang memiliki potensi sebagai pramuwisata. Pelatihan pemandu wisata dimaksudkan untuk meningkatkan kualitas sumber daya masyarakat lokal dalam penerimaan wisatawan yang berkunjung ke Desa Wisata Tablanusu. Pelatihan pemandu wisata ini diikuti oleh 25 orang masyarakat lokal Desa Tablanusu mayoritas anggota pelatihan ini terdiri dari pemuda - pemudi yang dilatih berbahasa Inggris untuk mempersiapkan diri menyambut wisatawan mancanegara untuk ke depannya.

b. Program pelatihan selam tingkat lanjutan dan tingkat rescue yang diselanggarakan pada tahun 2013-2014 diikuti oleh 20 orang yang terdiri dari pemuda -pemudi merupakan program yang dibuat untuk meningkatkan potensi bagi masyarakat lokal. Tujuan utama dalam program ini yaitu memberikan pelatihan serta pengetahuan cara menyelam yang sesuai dengan prosedur yang benar. Dengan adanya pelatihan ini, diharapkan adanya kerjasama yang baik diantara masyarakat yang mengikuti pelatihan ini agar pelatihan yang dilakukan bermanfaat bagi kalangan luas.

\section{Partisipasi Masyarakat Desa Tablanusu dalam Sektor Informal}

Menurut Manning dan Effendi (1991), sektor informal merupakan suatu istilah yang mencakup dalam istilah usaha sendiri, merupakan jenis kesempatan kerja yang kurang terorganisir, persyaratan kerjanya jarang dijangkau oleh aturan hukum. Mereka adalah kumpulan pedagang, pekerja yang tidak terikat dan pekerja yang memiliki pendapatan tidak tetap.

Dari pemaparan di atas yang dimaksudkan sektor informal pada penelitian ini yaitu usaha-usaha yang dibuka oleh masyarakat Desa Tablanusu terdiri dari pengelola resort, karyawan resort, penagih gasebo, usaha depot galon, penyewaan pelampung, usaha homestay dan toilet umum, pengendara banana boat dan penyedia perahu. Semua usaha-usaha tersebut tergolong informal karena tergolong usaha berskala kecil yang memiliki 
tujuan mendistribusikan barang dan jasa kepada konsumen untuk mendapatkan keuntungan ekonomi.

\section{a. Pengelola Suwae Resort}

Dalam pelaksanaan terkait pengembangan pariwisata di Desa Tablanusu nampak jelas dengan adanya dukungan dari Bapak Habel Melkias Suwae selaku pemilik Suwae Resort. Dukungan serta kerjasama yang baik telah terjalin sejak ditetapkannya Desa Tablanusu sebagai desa wisata yang mampu menarik minat wisatawan untuk mengunjungi Desa Wisata Tablanusu. Sebagai pihak pengelola beliau memberikan dukungan penuh bagi masyarakat lokal untuk terlibat langsung dalam upaya pengembangan, baik dukungan secara material maupun motivasi. Salah satu upaya yang dilakukan Bapak Habel Suwae dalam pengembangan pariwisata di Desa Tablanusu nampak jelas dari keterlibatan beliau membangun Suwae Resort dan beberapa unit penginapan yang menjadi peluang bagi masyarakat untuk terjun dalam dunia pariwisata.

\section{b. Karyawan Suwae Resort}

Suwae Resort merupakan akomodasi berbintang tiga memberikan peluang kerja bagi masyarakat lokal. Hotel ini memiliki fasilitas yang disediakan bagi wisatawan yang berwisata dan ingin menginap di pantai Tablanusu. Hotel ini mempekerjakan 10 orang masyarakat lokal yang terdiri dari tiga pekerja pria dan tujuh pekerja wanita. Pengelola Suwae Resort memprioritaskan masyarakat lokal Desa Tablanusu sebagai karyawan. Salah satu karyawan bernama Erwin Yakarimilena sebagai pengawas umum dan kasir di Suwae Resort telah bekerja selama lima tahun seperti yang terlihat pada Foto 1. Diketahui bahwa pihak pengelola secara khusus menangani perekrutan karyawan untuk Suwae Resort, perekrutan karyawan tersebut berlandaskan pada program pemberdayaan masyarakat yang berfokus pada masyarakat lokal. Implikasi dari pemberdayaan masyarakat tersebut terwujud dengan mempekerjakan karyawan 
yang berasal dari masyarakat lokal Desa Tablanusu dengan harapan setiap karyawan yang bekerja turut berpartisipasi dalam menjaga lingkungan, ketentraman, serta keberlanjutan dari Desa Wisata Tablanusu.

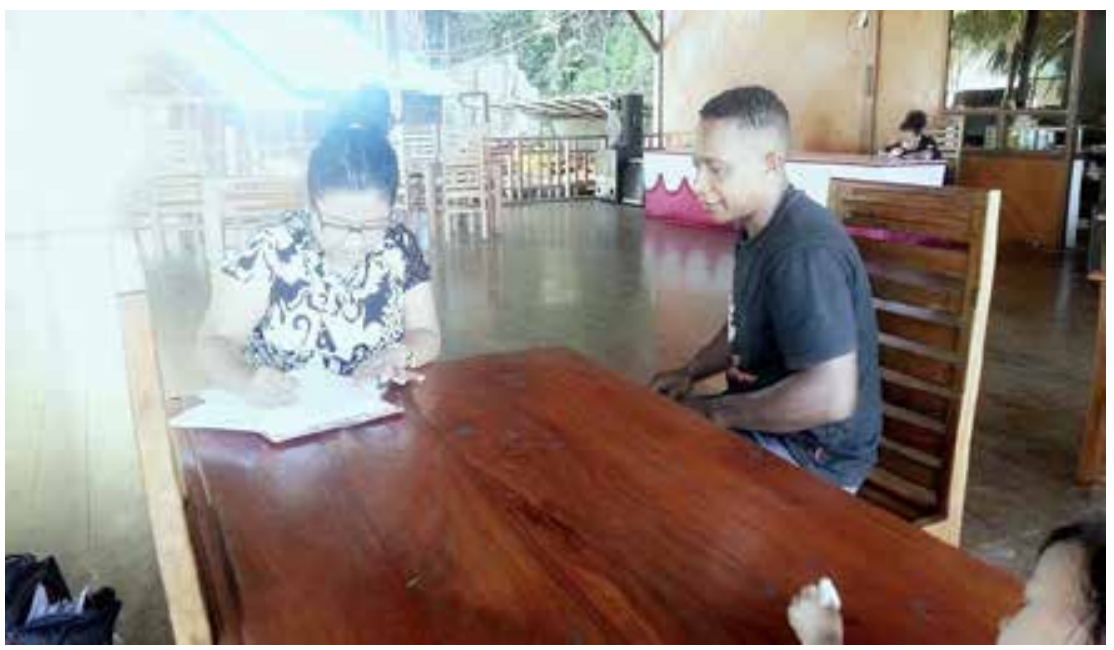

Foto 1 Karyawan di "Suwae Resort"

Sumber: Dokumentasi Peneliti (2015)

\section{c. Penagih Sewa Gasebo}

Gasebo adalah salah satu fasilitas umum yang disediakan untuk wisatawan yang berkunjung ke Desa Tablanusu. Dinas Kebudayaan dan Pariwisata Kabupaten Jayapura melalui PNPM Mandiri Pariwisata Tablanusu Desa Entiyebo Distrik Depapre ikut berperan dengan pengadaan sembilan unit pondok wisata atau gasebo. Setiap gasebo disewakan seharga Rp. 100.000. Gasebo yang ada diawasi oleh masyarakat lokal sebagai penagih tarif untuk setiap gasebo. Hal ini menjadi salah satu peluang bagi masyarakat lokal untuk terlibat dalam kegiatan pariwisata di desa ini. Partisipasi masyarakat lokal mulai nampak dengan adanya pengembangan di kawasan wisata Tablanusu. Seorang masyarakat lokal bernama Ibu Alfreda Somisu berusia 45 Tahun, yang bekerja sebagai penagih gasebo sekaligus bendahara di RT III. Adanya pengembangan pariwisata di Desa Tablanusu memberikan keuntungan dari faktor ekonomi. 


\section{d. Usaha Depot Air Galon}

Depot air galon berasal dari sumber mata air segar Dukumbru merupakan salah satu usaha di sektor informal yang dimiliki oleh masyarakat lokal Desa Tablanusu dapat dilihat pada Foto 2. Usaha ini dikembangkan sejak tahun 2011 hingga saat ini. Terbentuknya usaha ini merupakan salah satu dampak positif dari dimensi ekonomi yang berkembang di Desa Wisata Tablanusu. Satu galon isi ulang yang dijual seharga Rp.15.000, yang bisa diantarkan ke rumah konsumen. Penghasilan yang diperoleh setiap bulannya mencapai Rp. 3.000.000 selain itu juga pemilik depot ini menjelaskan bahwa dengan adanya pengembangan pariwisata di Desa Tablanusu berdampak pada usaha di sektor informal bagi masyarakat lokal Desa Tablanusu.

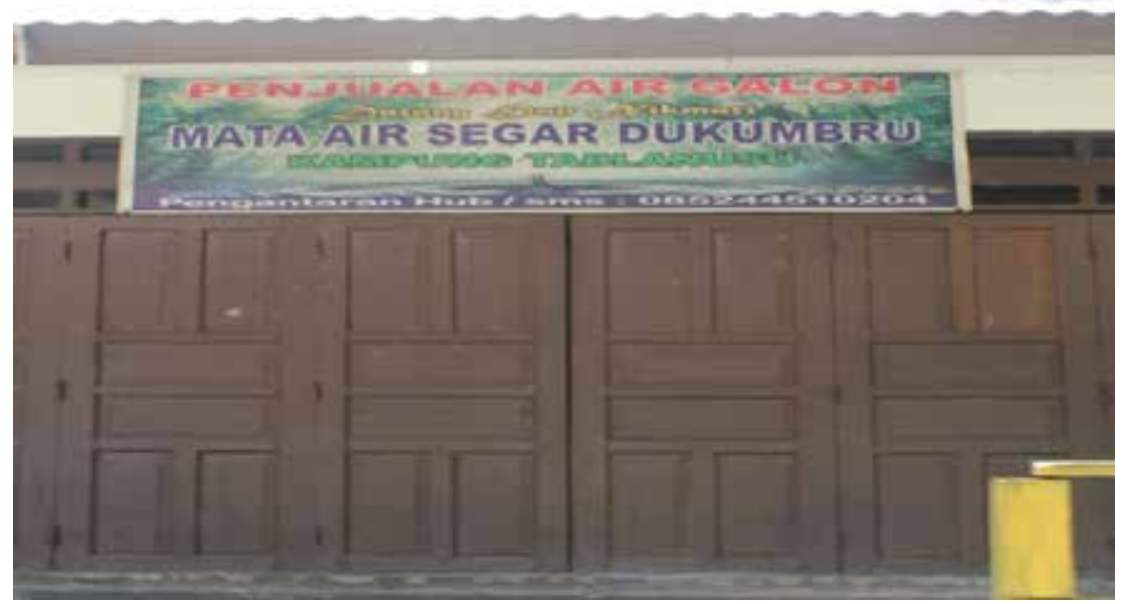

Foto 2. Depot air galon di Desa Tablanusu

Sumber: Dokumentasi Peneliti (2015)

\section{e. Penyewaan Pelampung}

Menyewakan pelampung merupakan salah satu bentuk partisipasi masyarakat Desa Tablanusu. Ban dalam yang digunakan sebagai pelampung dan alas tikar merupakan alatalat yang juga tersedia di pantai Tablanusu. Penyediaan alatalat ini disediakan disekitar pantai bagi wisatawan. Masyarakat 
lokal di Desa Tablanusu menjaga tempat penyewaan alat ini. Adanya keterlibatan masyarakat di sektor informal menambah pemasukan bagi masyarakat lokal.

\section{f. Pemilik Homestay dan Toilet Umum}

Homestay merupakan jenis akomodasi berupa rumah-rumah pribadidimanainteraksiterjadisecaraintensif.Tersedianyafasilitas akomodasi yang menunjang kegiatan pariwisata di kawasan Desa Tablanusu memberikan ide baru bagi masyarakat lokal untuk menyewakan rumah mereka sebagai homestay untuk wisatawan yang berkunjung ke pantai Tablanusu. Homestay yang disediakan berupa sebuah rumah panggung yang cukup besar dengan harga Rp. 600.000 per hari. Wisatawan yang biasanya menyewa rumah ini terdiri dari rombongan dari kegiatan keagamaan atau kegiatan perusahaan. Seorang penatua yang bernama Bapak Yosep Suwae kini ikut berpartisipasi menyewakan rumahnya sebagai homestay selain itu beliau memiliki 3 unit toilet umum. Dengan mengelola homestay, artinya masyarakat Desa Tablanusu ikut berpartisipasi dalam sektor informal.

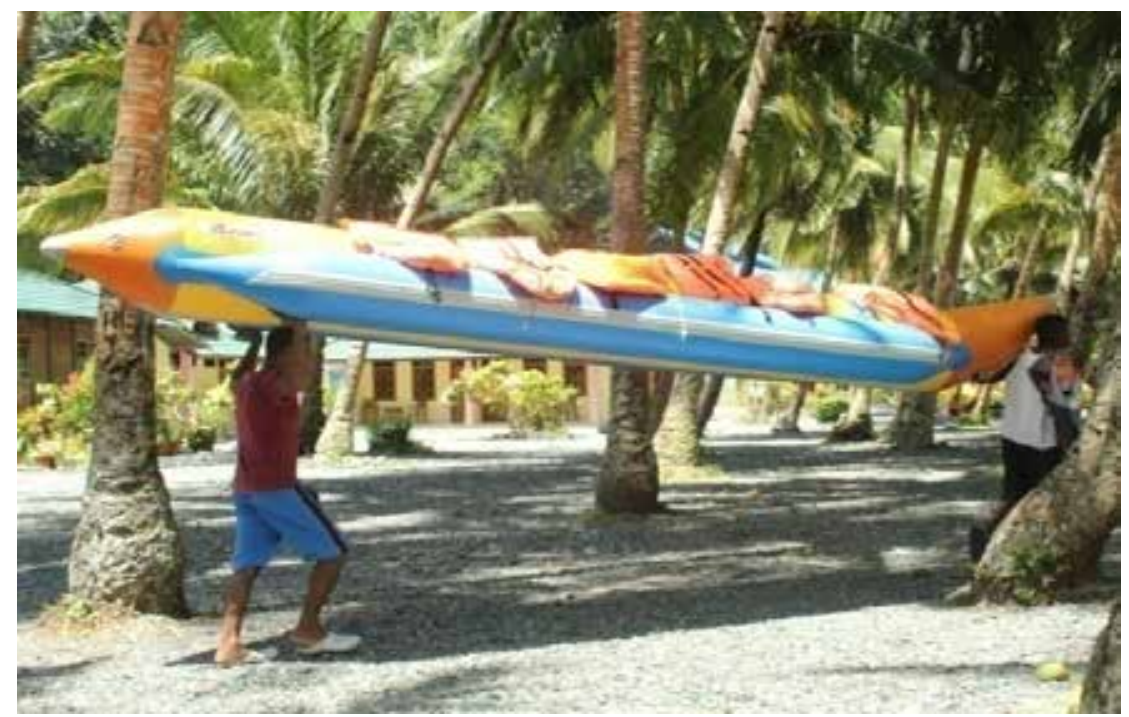

Foto 3. Partisipasi pemuda pengendara banana boat Sumber: Dokumentasi Peneliti (2015) 


\section{g. Pengendara Banana Boat}

Bentuk partisipasi di sektor informal yang dilaksanakan oleh masyarakat lokal sebagai pengendara wahana banana boat oleh pemuda Desa Tablanusu seperti yang terlihat pada Foto 3. Perkembangan pariwisata di desa ini memberikan peluang bagi pemuda untuk ikut berpartisipasi serta mendapatkan penghasilan yang lebih. Wahana banana boat menjadi salah satu daya tarik bagi wisatawan untuk berkunjung ke destinasi wisata ini, dimana wisatawan akan diajak berkeliling pantai Tablanusu menikmati indahnya panorama pantai Tablanusu. Banana boat itu sendiri dimiliki oleh pihak pengelola Suwae Resort namun pengelola memberikan kesempatan bagi para pemuda untuk berpartisipasi dengan menjadi pengendara wahana ini.

\section{h. Penyedia Jasa Perahu}

Berkembangnya pariwisata di Desa Tablanusu berdampak pula pada perkembangan salah satu aksesibilitas yang digunakan untuk mencapai Desa Tablanusu. Masyarakat lokal yang memiliki perahu tempel yang disewakan sebagai alat transportasi laut untuk menyebrang ke Desa Tablasupa, pantai Amay dan pulau lainnya yang dapat ditempuh dengan perahu ini. Tarif untuk transportasi laut ini yaitu Rp.10.000. Perahu tempel atau perahu Jonson ini bukan hanya digunakan sebagai alat transportasi umum dikalangan masyarakat Tablanusu, tetapi juga disewakan kepada wisatawan yang ingin berkeliling wilayah pantai Tablanusu dan Tablasupa. Biaya untuk menyewa perahu itu sekitar Rp. 200.000 sampai Rp. 300.000. Masyarakat lokal yang bekerja sebagai penyedia jasa perahu menjelaskan bahwa partisipasinya selama ini berdampak positif bagi peningkatan ekonominya. Selain mendapat keuntungan dari penyewaan perahu ini, juga turut berpartisipasi menjadi pemandu untuk menjelaskan tentang potensi bahari yang dimiliki oleh Desa Tablanusu.

\section{i. Pedagang Wisata Kuliner}

Wisata kuliner menjadi salah satu wisata alternatif yang 
menarik minat wisatawan untuk berkunjung ke suatu destinasi. Oleh sebab itu, setiap daerah tujuan wisata berupaya menggali dan melestarikan kuliner daerahnya. Hal ini tercermin dari upaya yang dilakukan oleh aparat Desa Tablanusu bekerjasama dengan pihak pengelola kepada masyarakat lokal untuk berpartisipasi memperkenalkan kuliner lokal yang kaya akan citra rasa nya kepada wisatawan. Kuliner lokal yang disajikan kepada wisatawan disediakan di restauran Tablanusu yang lokasinya berhadapan dengan "Suwae Resort". Jenis makanan dan minuman yang disajikan seperti papeda sebagai salah satu makanan khas Papua, ikan bakar lengkap dengan sambal colo-colo, sate ulat sagu, ikan asar atau yang dikenal dengan ikan asap serta sagu kering.

Kegiatan kepariwisataan yang ada di Desa Tablanusu saat ini mulai meningkatkan kesejahteraan masyarakat yang tinggal di sekitarnya. Masyarakat yang membuka usaha sektor informal di Desa Tablanusu, memiliki peran tersendiri dalam mendukung pengembangan kegiatan pariwisata di Desa Tablanusu. Masyarakat yang membuka usaha sektor informal di Desa Tablanusu, berhak memberikan aspirasi mengenai program-program serta kebijakan yang dibuat oleh pengelola di Desa Tablanusu. Demikian pula apabila masyarakat yang membuka usaha di Desa Tablanusu memiliki saran atau ide untuk merencanakan kegiatan-kegiatan yang mendukung pengembangan kepariwisataan di Desa Tablanusu.

Dalam hal pembuatan kebijakan terkait dengan kegiatan operasional masyarakat yang membuka usaha sektor informal, pengelola memberikan kesempatan bagi masyarakat untuk menyampaikan pendapat. Contoh paling konkrit adalah dalam pembuatan keputusan untuk izin berjualan bagi masyarakat. Kebijakan yang dibuat yaitu adanya pembatasan area berjualan bagi masyarakat yang ditetapkan sesuai dengan wilayah RT masing-masing dan diberlakukannya aturan yang dapat berpartisipasi di Desa Tablanusu yaitu masyarakat lokal yang berasal dari Desa Tablanusu, tidak dizinkan bagi orang luar untuk terlibat dalam partisipasi di Desa Tablanusu. Kebijakan ini dibuat berdasarkan aspirasi masyarakat dengan tujuan untuk 
pemerataan hasil bagi masyarakat lokal Desa Tablanusu.

Secara umum, dalam musyawarah rutin yang diadakan oleh pengelola, masyarakat yang terlibat dalam usaha sektor informal dapat menyampaikan pendapat terkait program-program serta kebijakan yang dilakukan oleh pengelola. Meskipun demikian, beberapa saran atau inisiatif yang dinilai kurang sesuai dengan konsep yang diterapkan oleh pihak pengelola tidak akan ditindaklanjuti. Pengelola memegang kendali terhadap seluruh kebijakan yang berkaitan dengan kegiatan kepariwisataan di Desa Tablanusu.

Tingkat partisipasi masyarakat dalam sektor informal di Desa Tablanusu dianalisis dengan teori partisipasi menurut Arnstein (1969) berada pada tahapan konsultasi. Pada tahapan konsultasi, hakekat kesertaan masyarakat berada pada posisi masyarakat didengar, namun tidak selalu dipakai sarannya. Pada tangga partisipasi ini komunikasi telah bersifat dua arah yaitu komunikasi antara pihak pengelola dan masyarakat, tapi masih bersifat partisipasi yang ritual.

\section{Partisipasi Masyarakat dalam Pengawasan}

Proses pengawasan dilakukan untuk memastikan seluruh rangkaian kegiatan yang telah direncanakan, dan dilaksanakan dapat berjalan sesuai dengan target yang diharapkan sekalipun berbagai perubahan terjadi. Terkait dengan pengawasan terhadap program-program yang telah dirancang dan dilaksanakan di Desa Wisata Tablanusu, pengawasan dilakukan oleh Dinas Pariwisata dan Ekonomi Kreatif Provinsi Papua, Dinas Kebudayaan dan Pariwisata Kabupaten Jayapura serta pihak pengelola. Bentuk pengawasan yang dilakukan seperti peninjauan fasilitas-fasilitas pariwisata yang dibangun oleh pihak pemerintah, peninjauan terhadap pelaksanaan program-program pengembangan dan pegawasan terhadap tingkat keberhasilan program-program yang telah dilaksanakan untuk pengembangan pariwisata di Desa Tablanusu.

Bentuk pengawasan yang dilakukan oleh aparat desa yaitu 
membuat beberapa ketentuan dan tata tertib kepada masyarakat yang berpartisipasi di sektor informal. Masyarakat yang bekerja sebagai pedagang yang berjualan di sekitar kawasan pantai Tablanusu, diberlakukan aturan tata tertib berupa kewajiban gotong royong dalam menjaga kebersihan wilayah pantai bagi semua pedagang. Aturan ini dibuat sebagai bentuk pengawasan terhadap kegiatan pariwisata di Desa Tablanusu untuk mengantisipasi para pedagang yang tidak memenuhi aturan yang dibuat. Hal ini menunjukkan bentuk pengawasan dari pihak aparat desa bekerjasama dengan pihak pengelola dalam menegakkan tata tertib agar pengembangan pariwisata di Desa Tablanusu dapat berlangsung secara optimal.

Selain pengawasan, tahap evaluasi juga dilakukan oleh pemerintah bekerjasama dengan aparat desa, pihak pengelola dan masyarakat. Evaluasi yang dilakukan lebih difokuskan pada pengembangan sumber daya manusia di Desa Tablanusu. Evaluasi ini bertujuan untuk mengembangkan potensi-potensi yang dimiliki oleh masyarakat lokal Desa Tablanusu. Evaluasi yang dilaksanakan oleh pemerintah terkait dengan pengembangan sumber daya manusia di Desa Tablanusu yaitu menyelenggarakan pembinaan dan pengembangan serta penyuluhan pariwisata, menyiapkan bahan kerjasama dan penyelenggaraan pembinaan pariwisata terhadap masyarakat lokal di Desa Tablanusu.

Pada tahap pengawasan hingga evaluasi berdasarkan teori partisipasi Arnstein (1969), bentuk partisipasi masyarakat berada pada tahap informasi (information). Pada jenjang ini komunikasi sudah mulai banyak terjadi tetapi masih bersifat satu arah dan tidak ada sarana timbal balik. Informasi telah diberikan kepada masyarakat Desa Tablanusu tetapi masyarakat tidak diberikan kesempatan melakukan tangapan balik (feed back). Pada tahap pengawasan komunikasi antara masyarakat dengan pihak pemerintah sudah banyak terjadi namun hanya bersifat satu arah yaitu berfokus pada peran pemerintah mengawasi programprogram yang dibuat, mengawasi fasilitas yang dibangun oleh pihak pemerintah. Masyarakat diberi informasi terkait 
pengawasan yang dilakukan namun masyarakat tidak diberi kesempatan untuk memberikan tanggapan balik, sehingga dalam tahap pengawasan dan evaluasi masyarakat hanya sebagai penerima informasi dari pemerintah terkait.

\section{Simpulan dan Saran}

Berdasarkan hasil pembahasan dan analisis dari penelitian yang dilakukan maka dapat disimpulkan hal-hal sebagai berikut. Bentuk partisipasi masyarakat dalam pengembangan pariwisata di Desa Tablanusu meliputi tahap perencanaan, pelaksanaan dan pengawasan. Pada tahap perencanaan masyarakat Tablanusu telah dapat berkomunikasi namun bersifat terbatas. Inisiatif datang dari pemerintah dan hanya satu arah. Masyarakat diberikan kesempatan untuk berpendapat dan didengar pendapatnya, tetapi mereka tidak memiliki kemampuan untuk mendapatkan jaminan bahwa pandangan mereka akan dipertimbangkan oleh pihak pemerintah.

Bentuk partisipasi masyarakat lokal Desa Tablanusu pada tahap pelaksanaan terbagi menjadi dua yaitu pelaksanaan partisipasi terkait dengan program-program yang dirancang oleh pemerintah dan partisipasi masyarakat di sektor informal. Pada pelaksanaan program yang dibuat oleh pemerintah, programprogram tersebut yakni pelaksanaan bimbingan teknis penguatan ketrampilan bidang kepemanduan wisata lokal bagi kelompok sadar wisata (POKDARWIS) dan program pelatihan selam tingkat lanjutan dan tingkat rescue. Masyarakat memiliki hak untuk menindaklanjuti program-program yang diberlakukan oleh pemerintah. Partisipasi masyarakat relatif tidak ada komunikasi dan dialog, tujuan sebenarnya bukan untuk melibatkan masyarakat dalam perencanaan dan pelaksanaan program tetapi untuk mendidik masyarakat. Sedangkan partisipasi masyarakat di sektor informal yaitu usaha-usaha yang dibuka oleh masyarakat Desa Tablanusu terdiri dari pengelola resort, karyawan resort, penagih sewa gasebo, usaha depot galon, penyewaan jasa pelampung, usaha homestay dan toilet umum, pengendara banana boat dan penyedia jasa perahu. Tingkat partisipasi masyarakat di 
sektor informal diketahui bahwa pendapat serta saran masyarakat didengar, namun tidak selalu dipakai sarannya.

Tingkat partisipasi masyarakat dalam pengawasan dan pengevaluasian program-program pengembangan pariwisata berada pada tahap informasi (information). Komunikasi antara masyarakat dengan pihak pemerintah sudah banyak terjadi namun hanya bersifat satu arah yaitu berfokus pada peran pemerintah mengawasi program-program yang dibuat, mengawasi fasilitas yang dibangun oleh pihak pemerintah. Masyarakat diberi informasi terkait pengawasan yang dilakukan namun masyarakat tidak diberi kesempatan untuk memberikan tanggapan balik, sehingga dalam tahap pengawasan dan evaluasi masyarakat hanya sebagai penerima informasi dari pemerintah terkait.

Saran yang dapat direkomendasikan kepada pihakpihak terkait dari hasil pembahasan yaitu pemerintah perlu meningkatkan kualitas sumber daya manusia dan membangun infrastruktur pariwisata yang masih kurang. Bagi pengelola perlu adanya kerjasama yang baik antara pemerintah sebagai fasilitator, dan masyarakat lokal untuk bekerja sama sehingga kedatangan wisatawan dan segala aktivitas wisata yang berkembang di Desa Wisata Tablanusu dapat terkontrol dengan baik dengan pengawasan masyarakat. Selain itu perlu diadakan kegiatankegiatan yang berguna bagi pengembangan pariwisata di Desa Tablanusu. Bagi masyarakat, perlu menjaga kebersihan dan keamanan lingkungan dengan mempertahankan kelestarian potensi alam dan budaya yang ada di Desa Tablanusu.

\section{Daftar Pustaka}

Arnstein, S.R. 1969. A Ladder Citizen Participation. Diakses pada 30 Maret 2016. Tersedia pada: http://litgow- schmidt.dk/sherry-arnstein/ ladder-of-citizen-participation.html.

Hasibuan, M. 2011. Manajemen Sumber Daya Manusia. Jakarta: PT Bumi Aksara, Edisi Revisi.

Manning, C., Effendi, T.N., 1991. Urbanisasi, Pengangguran, dan sektor 
Ika Pujiningrum Palimbunga

informal di Kota, Jakarta: Yayasan Obor Indonesia.

Moleong, L.J., 2014. Metodelogi Penelitian Kualitatif. Bandung: PT Remaja Rosdakarya Press.

Nasikun. 1997. Model Pariwisata Pedesaan. Permodelan Pariwisata Pedesaan untuk Membangun Pedesaan yang berkelanjutan. Bandung: ITB

Pitana, I.G., 1999a. "A Community Management dalam Pembangunan Pariwisata" Majalah Ilmiah Pariwisata- Analisis Pariwisata Vol. 2. Program Studi Pariwisata. Universitas Udayana.

Pitana, I.G., 2002. "Kebijakan dan Strategi Pemerintah Daerah Bali dalam Pembangunan Pariwisata. Pada Seminar Nasional Pariwisata Bali the Last or the Lost Paradise". Pembangunan Pariwisata yang Berkelanjutan. Denpasar: Universitas Udayana.

Sacafirmansyah, 2009. Partisipasi Masyarakat. Diakses: 2 Februari 2015. Tersedia pada: https://sacafirmansyah.wordpress. com/2009/06/05/partisipasi-masyarakat/. Scheyvens, Regina. 2002. Tourism for Development: Empowering Communities. Singapore: Pearson Education Limited.

Slamet. 2003. Pembangunan Masyarakat Berwawasan Partisipasi. Surakarta: Sebelas Maret University Press.

Sunaryo, B., 2013. Kebijakan Pembangunan Destinasi Pariwisata Konsep dan Aplikasinya di Indonesia. Yogyakarta: Gava Media.

Yarisetouw, B., 2012. "Strategi Perencanaan Desa Tablanusu Distrik Depapre Sebagai Destinasi Pariwisata di Kabupaten Jayapura Provinsi Papua". (Tesis). Denpasar: Universitas Udayana.

\section{Profil Penulis}

Ika Pujiningrum Palimbunga, S.S., M.Par, menyelesaikan pendidikan Magister Kajian Pariwisata Universitas Udayana tahun 2016. Program Sarjana Strata I yang ditempuh adalah Jurusan Sastra Inggris pada Fakultas Sastra Universitas Negeri Papua Manokwari-Papua Barat diselesaikan pada tahun 2012. Pengalaman yang dimiliki adalah pernah mengajar Bahasa Inggris di Primagama di Manokwari, Papua Barat, mengajar di "The Best English Course" di Kota Denpasar, pernah menjadi penterjemah pada "Research concerning the Entomology Study in New Guinea, West Papua, The Papua Insects Foundation, sponsored by The World Wildlife Fund and the Dutch "Nationale Postcode Loterij"- Manokwari, Papua Barat". 